\title{
$\begin{array}{lllllllll}\text { I } & \mathrm{N} & \mathrm{S} & \mathrm{T} & \mathrm{I} & \mathrm{T} & \mathrm{U} & \mathrm{T} & \mathrm{E}\end{array}$
}

\section{Seventy-eight Percent of Working Rural Families to Receive Full Making Work Pay Tax Credit}

$\mathrm{T}$ The American Recovery and Reinvestment Act (ARRA) introduced a new tax credit to assist lowand middle-income working families. This Making Work Pay tax credit may become permanent, as President Obama has included it in his budget proposal. This credit is designed to help families hardest hit by the current economic recession and to promote fairness in the tax code. ${ }^{1}$ Families have already begun to see increases in their take home pay - generally at least $\$ 65$ per month ${ }^{2}$ - and because of the income distribution by place, a higher proportion of rural than suburban or central city families will realize this increase.

Nearly all working rural families will be able to claim the Making Work Pay tax credit and will realize an increase in take home pay immediately.

Through the Making Work Pay tax credit, taxpayers can receive up to a maximum of $\$ 400$ ( $\$ 800$ for married couples) to offset their tax burden. This credit phases in at the rate of 6.2 percent of earned income up to the maximum credit. Thus, it is only very low earners who will receive less than the full credit; to receive the full credit, individuals must earn at least $\$ 6,452$ and married couples must earn $\$ 12,903$. Those with high incomes (adjusted gross income greater than $\$ 75,000$, or $\$ 150,000$ for married couples) are eligible for a smaller benefit or no benefit. The credit is decreased by 2 percent of every dollar above the threshold. Thus, married couples with an adjusted gross income of $\$ 175,000$ would be eligible for a $\$ 300$ credit. At $\$ 190,000$, married couples are ineligible for the credit, and at $\$ 95,000$, single taxpayers receive no credit. ${ }^{3}$

The ARRA's website, http://www.recovery.gov/?q=content/ making-work-pay, provides a state-by-state breakdown of the number of families benefited by Making Work Pay and the total dollar amount. A summing of their estimates shows that the United States will spend $\$ 56.7$ billion to aid more

\section{MARYBETH J. MATTINGLY}

than 111 million families. Because of its wide eligibility, the Making Work Pay tax credit will benefit many American children.

Estimates from the data on families with children suggest:

- Making Work Pay is available to virtually all working poor families.

- Few families with children living in poverty (less than 2 percent) will be "lifted" out of poverty by this tax credit.

- Families in poverty represent only a small percentage (approximately 17 percent) of Making Work Pay recipients, because this credit will help families within a broad range of income.

- There is little variation in eligibility by place (rural: 88 percent of families, suburban: 85 percent of families, central city: 82 percent of families). All differences are driven by differences in income/marital status. Not all of those eligible qualify for the full credit.

- Over 35.6 million families with children are poised to benefit from the Making Work Pay tax credit.

The distribution of eligibility for the Making Work Pay tax credit is further broken down in Table 1. Table 1 shows the estimated percentage of American families with children who are eligible for part or all of the credit by place. Most families are eligible for the full credit, with rural families the most likely to be eligible (an estimated 78 percent). However, nearly one in ten families has no earnings and will receive no credit, although this is less the case in the suburbs. Few families have incomes that are too high for the maximum credit; such families are least common in rural America, where only 5 percent of families have income that deflates or diminishes their tax credit. In contrast, 16 percent of suburban families and 11 percent of families residing in central cities will receive no credit or less than the full credit because of high income. 
TAble 1: Family eligibility for the Making Work Pay tax CRedit

\begin{tabular}{cccccc}
\hline & $\begin{array}{c}\text { No Earnings, } \\
\text { No Credit }\end{array}$ & $\begin{array}{c}\text { Low Earnings, } \\
\text { Less Than Full Credit }\end{array}$ & Full Credit & $\begin{array}{c}\text { High Income, } \\
\text { Less Than Full Credit }\end{array}$ & $\begin{array}{c}\text { High Income, } \\
\text { No Credit }\end{array}$ \\
\hline U.S. Total* $_{\text {Rural }}$ & $9 \%$ & $5 \%$ & $74 \%$ & $6 \%$ & $6 \%$ \\
Suburban & $10 \%$ & $7 \%$ & $78 \%$ & $3 \%$ & $2 \%$ \\
Central City & $7 \%$ & $3 \%$ & $74 \%$ & $8 \%$ & $8 \%$ \\
\hline
\end{tabular}

* Includes places not identified by the Census Bureau

† Insufficient sample size for estimating this percentage.

Source: Current Population Survey 2008 Annual Social and Economic Supplement

\section{Data}

This analysis is based upon estimates from the 2008 Annual Social and Economic Supplement to the Current Population Survey (CPS). This is a family-level analysis based on family reference persons, with information about their spouse (if married) and children. Only families with dependent children are included in the analyses. Dependent children include own children and other identifiable related children in the family who are under 18 years of age, or 18 to 23 years old and attending school full time, and own disabled children regardless of age. Note that these estimates based on CPS data do not include all possible nuanced family tax situations and do not consider differences for non-citizens. The analyses assume married couples with a spouse present file joint income tax returns and assume only one tax filing unit per family. The CPS does not collect detailed tax information, thus estimates are based on reported earnings and total income. CPS estimates of adjusted gross income are top-coded such that they overestimate eligibility for the Making Work Pay tax credit. These analyses, instead, rely on total own (and spousal) unadjusted income, and as such may underestimate some cases of eligibility. Family income, poverty thresholds, and earnings refer to tax year 2007 and have been converted to 2009 dollars using the Bureau of Labor Statistics Inflation Calculator. All analyses are weighted to adjust for sampling.

\section{ABOUT THE AUTHOR}

Beth Mattingly is a family demographer at the Carsey Institute.(beth.mattingly@unh.edu)

\section{A C K N OW L E D G M E N T S}

The author thanks Arloc Sherman at the Center for Budget and Policy Priorities, Elizabeth Kneebone at the Brookings Institution, and Mil Duncan and Anne Shattuck at the Carsey Institute for their feedback in preparing this fact sheet.

\section{E N D N O T E S}

1 See http://www.recovery.gov/?q=content/making-workpay, accessed April 17, 2009.

2 Ibid.

3 See http://www.irs.gov/newsroom/ article/0,,id=204447,00.html, accessed April 17, 2009.

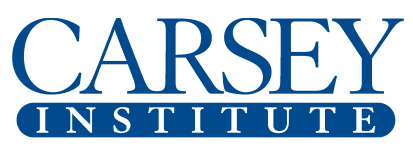

Building knowledge for families and communities

The Carsey Institute conducts policy research on vulnerable children, youth, and families and sustainable community development. We give policymakers and practitioners timely, independent resources to effect change in their communities.

The Carsey Institute is supported by the Annie E. Casey Foundation's initiative to strengthen rural families and by the W.K. Kellogg Foundation.

Huddleston Hall

73 Main Street

Durham, NH 03824

(603) 862-2821

www.carseyinstitute.unh.edu 